\title{
JOURNAL.RU
}

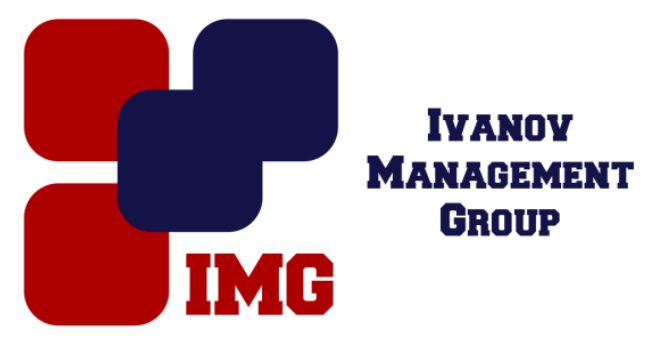

Филиппова Е.Н., Белякин А.А. Мордовский государственный педагогический институт имени М. Е. Евсевьева Саранск, Россия

doi: 10.18411/1j-31-05-2017-31

idsp 000001:1j-31-05-2017-31

\section{Исследование психического состояния юных футболистов в процессе спортивной деятельности}

В настоящее время часто наблюдается несоответствие уровня физической, технической и психологической подготовленности юных спортсменов требованиям соревновательной деятельности. Ранняя специализированная подготовка, значительный объем соревновательных нагрузок и связанный с этим стресс негативно влияют на психическое состояние юных спортсменов [1].

Вместе с тем успешность тренировочной и соревновательной деятельности в юношеском спорте определяется в первую очередь рациональным построением и содержанием тренировочных нагрузок, своевременной информацией о функциональном и психическом состоянии юных спортсменов [2].

Рассматривая подготовку спортсмена в психолого-педагогическом аспекте, целесообразно, прежде всего, остановится на формировании мотивов, определяющих отношение к спортивной деятельности; воспитании волевых качеств, необходимых для успеха в спорте; совершенствовании специфических психических возможностей.

В нашем исследовании приняли участие 12 футболистов в возрасте 12-13 лет. Для определения психического состояния в процессе тренировочной деятельности применялись тесты Кондаша и Ч.Спилбергера-Ю.Ханина. Данные тесты, сравнительно простые в применении, использовались для определения у испытуемых уровня тревожности - одного из основных состояний на данный момент времени (рисунок 1). 


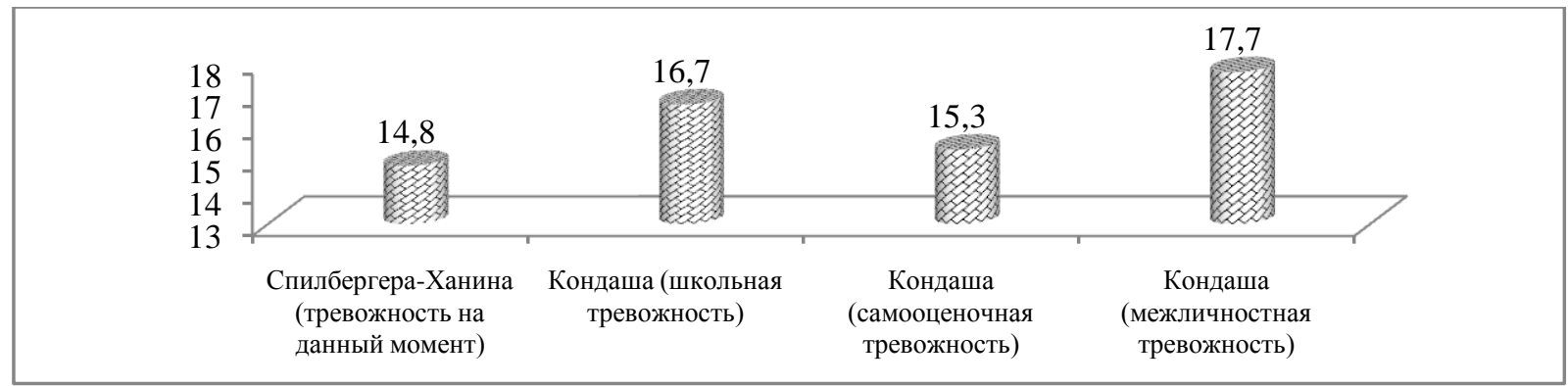

Рисунок 1 - Показатели психического состояния юных футболистов в начале подготовительного периода

Результаты оценки психологического состояния испытуемых указывают на то, что у всех футболистов наблюдается повышенный уровень тревожности.

Таким образом, исследовав уровень тревожности, мы предложили увеличить занятия на специально-силовую подготовку (таблица 1).

Таблища 1

Недельный цикл подготовительного периода тренировки

\begin{tabular}{|c|c|c|c|}
\hline Дни недели & Преимущественная направленность занятий & $\begin{array}{l}\text { Продолжитель } \\
\text { ность занятий, } \\
\text { мин }\end{array}$ & Нагрузка \\
\hline $\begin{array}{c}\text { Понедельни } \\
\text { к }\end{array}$ & $\begin{array}{c}\text { Совершенствование индивидуального технического } \\
\text { мастерства. } \\
\text { Развитие быстроты и ловкости с использованием } \\
\text { неспецифических упражнений. }\end{array}$ & $\begin{array}{l}45 \\
45\end{array}$ & $\begin{array}{c}\text { Малая } \\
\text { Средняя }\end{array}$ \\
\hline Вторник & $\begin{array}{c}\text { Специально-силовая подготовка в упражнениях с } \\
\text { мячом и без мяча. Прыжки, упражнения с } \\
\text { отягощениями. Игровые упражнения с заданием: } \\
\text { персональной опекой, быстротой выполнения, разной } \\
\text { скоростью перемещения. } \\
\end{array}$ & $\begin{array}{l}30 \\
30 \\
30\end{array}$ & $\begin{array}{l}\text { Средняя } \\
\text { Большая }\end{array}$ \\
\hline Четверг & $\begin{array}{c}\text { Совершенствование индивидуального технического } \\
\text { мастерства. Отработка силы и точности ударов ногой } \\
\text { и головой. }\end{array}$ & 90 & Большая \\
\hline Пятница & $\begin{array}{c}\text { Совершенствование индивидуального технического } \\
\text { мастерства. } \\
\text { Технико-тактическая подготовка в игровых } \\
\text { упражнениях (3x2; 4x2; 4x3; 6x6) со взятием ворот. }\end{array}$ & $\begin{array}{l}45 \\
45\end{array}$ & $\begin{array}{c}\text { Малая } \\
\text { Средняя }\end{array}$ \\
\hline Суббота & $\begin{array}{c}\text { Повышение общей и специальной выносливости в } \\
\text { игровых упражнениях } \\
\text { Совершенствование ловкости в упражнениях } \\
\text { технико-тактической направленности. } \\
\text { Акробатические упражнения с мячом. }\end{array}$ & $\begin{array}{l}45 \\
45\end{array}$ & $\begin{array}{l}\text { Средняя } \\
\text { Средняя }\end{array}$ \\
\hline
\end{tabular}

По окончанию подготовительного периода все испытуемые были повторно протестированы по ранее предложенным тестам (рисунок 2).

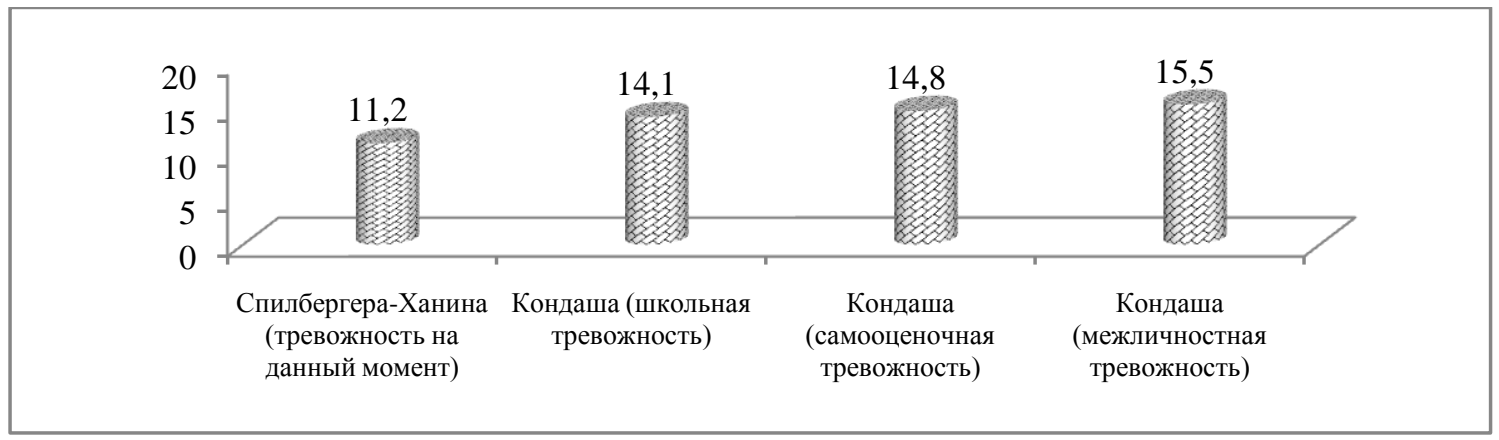

Рисунок 2 - Показатели психического состояния юных футболистов в конце подготовительного периода 
Анализируя показатели контрольно-педагогических испытаний можно отметить, что перед началом педагогического эксперимента исследуемые имели повышенный уровень тревожности, что выражалось в нестабильности игровых ситуаций и принятии решений. По окончании эксперимента (конец подготовительного периода) у всех испытуемых достоверно снизился показатель тревожности на данный момент (тест Спилбергера-Ханина) (p>0,05). Показатели тревожности по Кондашу, также имели тенденцию к снижению, но не столь достоверно $(\mathrm{p}<0,05)$. Можно говорить, что уровень физической и технической подготовленности у футболистов существенно возрос вследствие эффективности используемых организационно-методических условий с учетом уровня тревожности.

1. Филиппова, Е. Н. Зависимость уровня психологических параметров со спортивными результатами у юных лыжников-гонщиков в соревновательном периоде / Е. Н. Филиппова // Проблемы и перспективы физической культуры и спорта : сб. науч. тр. Киров: ВятГТУ, 2005. - С.177-183.

2. Филиппова, Е. Н.Особенности взаимодействия психологического состояния и соревновательной деятельности юных лыжников/ Е. Н. Филиппова, Н. А. Буянов // Тенденции развития науки и образования : сб. науч. тр. в 5 ч. Ч. 5.- Самара :Л-Журнал, 2016. - C. 21-23. 